\title{
Buyers Perception on Online Shopping in Kurdistan Region
}

\author{
Dr. Uma Shankar Singh \\ Faculty of Administrative Sciences and Economics \\ Tishk International University, Erbil-Kurdistan
}

\begin{abstract}
This study has been conducted in order to identify customer buying behavior in Kurdistan region towards online shopping. In order to do this the main question of this thesis was, what is consumer buying behavior toward online shopping in Iraqi Kurdistan Region? This will all be studied carefully and a survey questionnaire will be used in quantitative and also descriptive manner in order to analyze customer's feelings and thought which effect their behavior towards online shopping and finally the results will be analyzed by SPSS program which makes all data clear and understanding. Many literature reviews will be studied whether they are from the same region or from different countries, to further understand the case and to be able to answer the questions and reach the aims and objectives of the thesis. After going through all these steps, I was able to analyze all the data including primary and secondary data and was able to state my conclusion including recommendations which will help improve the process within the region and also will result in satisfied customers and better businesses.
\end{abstract}

Keywords: Buyer, perception, shopping, consumer, online

DOI: $10.7176 / \mathrm{EJBM} / 11-15-03$

Publication date:May $31^{\text {st }} 2019$

\section{Introduction}

Online shopping is a new technique of shopping which has appeared after all the new technological improvements and inventions, it has also appeared recently in the business and marketing area, but it developed rapidly all over the world. According to Marafie (2008) online shopping is much more efficient than traditional shopping because it is a time saver for customers. In Kurdistan this kind of technological marketing invention is recent and customers do not have enough information about this type of shopping yet, while in other countries like US and European countries it has become an important aspect for shopping in people's everyday lives. In some neighboring countries like Saudi Arabia, Kuwait, Turkey, and UAE, people are using online shopping more than Iraq and Kurdistan, because those countries are much more technologically developed than Kurdistan region. The percentage of using e-commerce in UAE is $25.1 \%$, Saudi Arabia is $14.3 \%$, and for Kuwait it is $10.7 \%$, the ecommerce share in Turkey's total retail was 1.7 percent in 2012, but it increased to 3.5 percent last year, a new (Marafie, 2008). There is no data available in Kurdistan in order to know the rate of users of online shopping and the aim for this research is to find out to what extent people in Kurdistan are shopping online and surfing the internet for shopping purposes, because Kurdistan is in the developing stage and after 2003 Kurdistan faced a rapid development in terms of technology, and its economy is booming, however for the past few years Kurdistan's economy has suffered a lot due to the wars and political issues.

It is noticeable that Kurdish people have recently started to use online retails to do shopping, however people are facing many issues while shopping online, and those problems differ from person to person. According to Sanati (n.d) e-commerce is a new kind of business to Kurdish people, because this kind of business is applied mostly in the developed countries. For developing countries such as Kurdistan, in order to have a successful online business, the first step to be taken is to build trust between your business and your customers, secure transaction and provide a good network for making payments online. One of the obstacles to online shopping in Kurdistan region is not having sufficient banking systems to pay directly for the products online, and IT illiteracy is another major problem that is an obstacle for implementing a good system for e-commerce in Kurdistan. Also there are other obstacles that affect Kurdish consumers which is facing difficulty during shopping online such as, demographic factor, environmental factor, product/service factor, reputation, trust, marketing, and security and protection of personal information. Those factors generally affect consumer behavior and in Kurdistan in order to know what the main factors are that affect consumer's behavior (Sanati, n.d.). A few studies were done in past keeping in mind the end goal to know buyer conduct toward web based shopping while customer chooses to purchase an item or administration. One of the inquiries about that was composed in past as respects of the customers web based shopping conduct was finished by Li and Zhang in (2002) and the title of the examination is "Buyer Online Shopping Attitudes and Behavior: An Assessment of Research" (Li \& Zhang, 2002). In this article writers are examined customers web based shopping conduct and state of mind through breaking down 35 experimental examinations which distributed in 9 IS diaries and meetings, and it was in the zone of Information System.

As indicated by $\mathrm{Li}$ and Zhang (2002) there are 10 factors which are interconnected together and have relationship, influences customers demeanor and conduct, for example, "outer condition, socioeconomics, 
individual attributes, merchant/benefit/item attributes, site quality, state of mind towards web based shopping, goal to shop on the web, internet shopping basic leadership, web based buying, and buyer fulfillment" (Li \& Zhang, 2002). This study showed that five of those factors are independent variable such as "external environment, demographics, personal characteristics, vender/service/product characteristics, and website quality" (Li \& Zhang, 2002), and the other five factors were dependent variable such as "attitude towards online shopping, intention to shop online, online shopping decision making, online purchasing, and consumer satisfaction." (Li \& Zhang, 2002). External environment implies that the variables which powers purchasers to shop on the web and it contains three degrees, for example, shielding customers from any sort of misfortune amid shopping on the web, outsider ID is the second extension, in which it demonstrates the dependability of the web based shopping venders, and the last extension is different contenders, for example, stores in web which have a similar administration and item (Li \& Zhang, 2002). Those three extensions are influencing the shoppers purchasing demeanor and conduct. Another factor which specified above is socioeconomics factor, since statistic factors influence the shoppers purchasing mentality and conduct, for example, age, sex, training, and wage.

\section{Literature Review}

E-business is the blend amongst innovation and business, and it is said that E-business can gather three diverse significant territories, for example, the human measurement, the mechanical segments and internet business. In this exploration the significant part that will be talked about is web based business which is one of the basic parts of e-business (Mirescu, n.d.). Web based business is purchasing and offering items and administrations through web. This sort of business began when innovation constrained organizations to enter online markets, and if any organization disregarded innovation previously, at that point right now they are compelled to utilize another administration and generation framework, all together not misfortune their market. Internet business has three segments, for example, business to business and business to shopper, and buyer to customer. Business to business is generally identified with describing merchandise and enterprises between organizations so as to get financial resources, yet business to customer is making buyers fulfilled by offering or purchasing products, administrations and data to shopper. The fundamental markets of this sort of web based business are e-shopping and e-keeping money. Purchaser to shopper is making business amongst buyers and one of the current and clear cases is e-sound (Mirescu, nd.). History of Electronic commerce is going back to its origin which appeared when EDI (Electronic Data Interchange) put into practice. EDI is swapping data from a computer to another through network connection (Mirescu, nd.). In the times of 70's and 80's this swapping was just to swap data and saving money exchanges, yet after 1983 web was the first and real information transmitter. The brilliant year of web shopping was in the vicinity of 1995 and 1999, in light of the fact that between those years numerous essential online retail sites set up, for example, Amazon, eBay and hurray. Amid this period numerous different organizations entered the online market, for instance, in 1997 USA's income was $\$ 707$ million, and afterward following a year it wind up 2.6 billion dollars and at 1999 it end up 5.8 billion dollars through the online market unrest (Mirescu, n.d.).

Consumer conduct is characterized by Kotler $(2004$, p.601) as "The purchasing conduct customers - people and families who purchase merchandise and enterprises for individual utilization." If we needed to make it all the more certain that buyer implies a man who does the way toward purchasing and devours the two products and ventures to fulfill his or her self. At the point when there will be communication amongst state of mind and feeling a sort of feeling will show up which is called customer conduct. The investigation of purchaser conduct causes the market to know customer conduct in the commercial center and it will prompts demonstrate the kinds of item that buyers will purchase or when, where and how regularly they get it. This term had been originated from showcasing idea and promoting idea is "business introduction that advanced in 1950's through a few option approaches, alluded to, separately, as the generation idea, the item idea and the offering idea." (Schiffman \& Kanuk, 2007). To have a strong successful customer relationship there should be three drivers which are customer value, high level of customer satisfaction, \& building a structure for customer retention (Schiffman \& Kanuk, 2007). In late 1950s the area of consumer behavior appeared in the strategy of marketing, and this was as the result of appearance of selling more products by marketers, and it helped marketers to produce only those products that consumers buy. The marketing concept came as the result of consumer oriented marketing philosophy and it is called marketing concept (Schiffman \& Kanuk, 2007). In order to have a successful the producer should know the needs and wants of the target market and to deliver the goods and products to the consumers better than its competitors. As the result those companies which pay attention to their customers are those who stay for longer and grow faster than the other who does not pay attention to their customers (Schiffman \& Kanuk, 2007).

Socioeconomics are a critical method to demonstrate the rate of the web clients since it has been discovered that the majority of the web clients are youthful taught and wealthier individuals. Individual attributes is another factor, and it is demonstrated that individuals who do shop online are "more accommodation arranged and less experience-situated" (Li \& Zhang, 2002). Additionally there are other essential factors, for example, social condition, particular of the items and administrations, commitment of the item, trust, and ability to burn through cash. Merchant/benefit/item qualities is another factor which influences customers conduct and state of mind 
toward web based shopping and this factor is alluded to the items which offers on the web, benefits that are given and highlights of the online store. They way which it influences buyers are the notoriety of the site, size of the store, dependability, guarantees of the items, physical area of the store, nature of the great, cost, diverse numbers if items, mark, accessibility of the item, brisk reaction to the purchasers, time viability, having returning and discounting strategy, great conveyance, shielding from misrepresentation, and consolation (Li \& Zhang, 2002). Nature of the site is another factor and this factor influences the customers purchasing conduct and state of mind for this reasons sites ought to rouse buyers, and the site ought to be secure and keep shoppers' security, and shielding them from dangers. Better site quality will rouse the purchaser to return to the site. Demeanor toward web based shopping is another factor, and this factor has been focused on additional in the majority of the investigations, since it demonstrates the acknowledgment of web based shopping by the customer, it indicates purchasers pondering a particular store, saw chance manages item/administrations monetary misfortunes, useful misfortune, losing time, and item chance, likewise protection, security, are other two saw dangers (Li \& Zhang, 2002). Likewise there are some vital viewpoints which increment the buyer's internet purchasing rate, for example, having enrollment, and strengthening of shoppers, control and satisfactions. Expectation to internet shopping is another factor, and it indicates how far purchasers will purchase on the web and it demonstrates unwaveringness of buyers toward the online store. Web based shopping basic leadership is another factor, and it contains discovering data, settling on the decision of purchasing the item, and looking at the items, since they influence purchaser's fulfillment. Internet obtaining is another factor that influences customer's state of mind and conduct toward web based shopping, and this factor is interrelated to the merchant/item/administrations trademark, site quality, mentalities toward web based shopping, expectation to shop on the web, and basic leadership. Last factor is Consumer Satisfaction, and this factor is demonstrates the desire of customers toward web based shopping that are accessible amid shopping on the web, since desires are additionally having sway on dispositions for shopping in a particular online store, and it likewise have effect on basic leadership and buying conduct by purchasers, on the grounds that if buyers accomplished their desires the level of shopper fulfillment will increment (Li \& Zhang, 2002).

\section{Research Problem}

Different studies has been done in order to know consumers behavior toward online shopping in general, and Zheng (2006) in his examination consolidated past investigations and research which was done before about web based shopping and they routes for building up viable web based advertising channel, and the effect which web shopping has on its purchaser's conduct. This exploration will help a web based business for fortify its advertising technique. The point of this exploration is to distinguish the current status of web clients in UK and China, and this examination is recognizing the effect of web shopping on purchaser purchasing conduct. For finding the responses for the examination addresses, a review survey had been done in UK and China. Every one of the respondents of this review survey has specified that they all have web get to on the grounds that the poll was sent through email to the respondents, and they all had web access in their home and their working environments. The study is assessing the acceptance of online shopping by the Kurdish population as the world is changing and Kurdistan is highly exposed with international population who are seeking many products from different corners of the world.

\section{Research Objectives}

For this specific study the research is concentrating on finding the solution for the problem formulated and to reach the solution the following research objectives prepared are:

- To assess the level of online shopping usage in Kurdistan

- To categorize the factors that has effect on perception of Kurdish consumer to buy online.

- To classify the factors that influence Kurdish consumer to implement online shopping in Kurdistan.

\section{Research Methodology}

The nature of this research requires two types of approaches which are both qualitative and quantitative approaches. Quantitative research approach is using the process of one-on-one in which the researcher is questioning people directly. This type of study is made for analyzable data study and collected data in quantitative approach are numerical data (Hughes, 2006). "Quantitative research is based more directly on its original plans and its results are more readily analyzed and interpreted" (Hughes, 2006). According to this definition quantitative research is much easier to analyze than any other research approaches, and it depends on the large amount of data in a form of number. Possible approach to my research is quantitative approach. The research strategy is shows the direction of the research such as how the writer goes for the research for simplifying research objectives, research questions, and limitations and ethical issues that faces the researcher. There are many research strategies which have been used before in different types of studies. But the most important procedure is to choose the best and appropriate research strategy for the research. This research's research strategy will be survey and explanatory because the 
collection of data will be based on survey, and also interview will be another type of data collection and the way which it introduces the research is explaining the answers of interviewees. This research is based on both types of the data primary and secondary data. Secondary data are through previous studies which have been done before, and case studies, articles, and journal articles which are beneficial for this research. Primary data is through questionnaire collected from people who will be the sample of this study.

To meet the goal and objectives of the research the sample of the research plays an important role. The survey will be held mostly in university, institutions, and shopping malls, because university students have adequate information about computer and internet. Sample size will be around 100 samples, and the collected information will be adequate enough for representing the whole cities because the questionnaire will be based on convenience sampling. This type of sampling is beyond the researcher's control and the data collection procedure will continue until the researcher gets the sample size that he/she wants, and in this kind of sampling there will be choosing those cases which are simple for getting them for the research. This kind of sampling used widely and it influences those who are under the researcher's control. This research's data collection instrument is through survey questionnaire so as to target the large participants and to have the accurate results. Quantitative data are numeric data and there are several programs which are useful for analyzing the data, and the programs which will be used in this research for analyzing the collected quantitative data will be SPSS program.

\section{Data Analysis and Findings}

The number of copies which got back from the participants are 98 copies and the survey done among several types of people in society. The survey consisted of 20 items.

Table 1: Reliability Statistics

\begin{tabular}{|c|c|}
\hline \multicolumn{2}{|c|}{ Reliability Statistics } \\
\hline Cronbach's Alpha & N of Items \\
\hline .949 & 15 \\
\hline
\end{tabular}

As shown in above Table 1, the reliability of this research questionnaire has turned out to be very reliable and justifies that respondents have provided good responds that are reliable and useful to analyze and prepare data for the study.

Table 2: Descriptive Statistics

\begin{tabular}{|c|c|c|c|}
\hline \multicolumn{2}{|l|}{ Parameters } & \multirow{2}{*}{$\begin{array}{l}\text { Frequency } \\
48 \\
\end{array}$} & \multirow{2}{*}{$\begin{array}{l}\text { Percentage } \\
49.0 \\
\end{array}$} \\
\hline Gender & Male & & \\
\hline & Female & 50 & 51.0 \\
\hline \multirow[t]{5}{*}{ Age } & 16 Years -20 Years & 07 & 7.1 \\
\hline & 20 Years -25 Years & 14 & 14.3 \\
\hline & 25 Years -30 Years & 41 & 41.8 \\
\hline & 30 Years -40 Years & 31 & 14.0 \\
\hline & 40 Years and Above & 05 & 31.6 \\
\hline \multirow{4}{*}{ Education } & High School & 8 & 8.2 \\
\hline & Bachelor & 56 & 57.1 \\
\hline & Master & 33 & 33.7 \\
\hline & Ph.D. & 01 & 1.0 \\
\hline \multirow[t]{6}{*}{ Monthly Salary } & Below USD 500 & 04 & 4.1 \\
\hline & USD 500 - USD 1000 & 04 & 4.1 \\
\hline & USD 1000 - USD 1500 & 10 & 10.2 \\
\hline & USD 1500 - USD 2500 & 52 & 53.1 \\
\hline & USD 2500 - USD 3500 & 23 & 23.5 \\
\hline & USD 3500 and Above & 05 & 05.1 \\
\hline \multirow{5}{*}{$\begin{array}{l}\text { I get on time delivery by shopping } \\
\text { online }\end{array}$} & Strongly Agree & 13 & 13.3 \\
\hline & Agree & 42 & 42.9 \\
\hline & Neutral & 18 & 18.4 \\
\hline & Disagree & 14 & 14.3 \\
\hline & Strongly Disagree & 11 & 11.2 \\
\hline \multirow{5}{*}{$\begin{array}{l}\text { Detail information is available } \\
\text { while shopping online }\end{array}$} & Strongly Agree & 12 & 12.2 \\
\hline & Agree & 38 & 38.8 \\
\hline & Neutral & 24 & 24.5 \\
\hline & Disagree & 16 & 16.3 \\
\hline & Strongly Disagree & 8 & 8.2 \\
\hline
\end{tabular}




\begin{tabular}{|c|c|c|c|}
\hline \multicolumn{2}{|l|}{ Parameters } & \multirow{2}{*}{$\begin{array}{l}\text { Frequency } \\
19\end{array}$} & \multirow{2}{*}{$\begin{array}{l}\text { Percentage } \\
19.4\end{array}$} \\
\hline I can buy the products anytime a & Strongly Agree & & \\
\hline day while shopping online & Agree & 33 & 33.7 \\
\hline & Neutral & 20 & 20.4 \\
\hline & Disagree & 15 & 15.3 \\
\hline & Strongly Disagree & 11 & 11.2 \\
\hline \multirow{5}{*}{$\begin{array}{l}\text { It is easy to compare products } \\
\text { while shopping online }\end{array}$} & Strongly Agree & 16 & 16.3 \\
\hline & Agree & 28 & 28.6 \\
\hline & Neutral & 23 & 23.5 \\
\hline & Disagree & 21 & 21.4 \\
\hline & Strongly Disagree & 10 & 10.2 \\
\hline \multirow{5}{*}{$\begin{array}{l}\text { The website design helps me in } \\
\text { searching the products easily }\end{array}$} & Strongly Agree & 18 & 18.4 \\
\hline & Agree & 36 & 36.7 \\
\hline & Neutral & 23 & 23.5 \\
\hline & Disagree & 13 & 13.3 \\
\hline & Strongly Disagree & 8 & 8.2 \\
\hline \multirow{5}{*}{$\begin{array}{l}\text { I prefer to purchase from a website } \\
\text { that provides safety }\end{array}$} & Strongly Agree & 24 & 24.5 \\
\hline & Agree & 30 & 30.6 \\
\hline & Neutral & 22 & 22.4 \\
\hline & Disagree & 13 & 13.3 \\
\hline & Strongly Disagree & 9 & 9.2 \\
\hline \multirow{5}{*}{$\begin{array}{l}\text { Website layout helps in searching } \\
\text { and selecting products }\end{array}$} & Strongly Agree & 17 & 17.3 \\
\hline & Agree & 32 & 32.7 \\
\hline & Neutral & 30 & 30.6 \\
\hline & Disagree & 12 & 12.2 \\
\hline & Strongly Disagree & 07 & 7.1 \\
\hline \multirow{5}{*}{$\begin{array}{l}\text { Familiarity with website before } \\
\text { purchasing reduces risks }\end{array}$} & Strongly Agree & 23 & 23.5 \\
\hline & Agree & 23 & 23.5 \\
\hline & Neutral & 31 & 31.6 \\
\hline & Disagree & 13 & 13.3 \\
\hline & Strongly Disagree & 08 & 8.2 \\
\hline \multirow{5}{*}{$\begin{array}{l}\text { I prefer to buy from website that } \\
\text { provides quality information }\end{array}$} & Strongly Agree & 28 & 28.6 \\
\hline & Agree & 20 & 20.4 \\
\hline & Neutral & 26 & 26.5 \\
\hline & Disagree & 10 & 10.2 \\
\hline & Strongly Disagree & 14 & 14.3 \\
\hline \multirow{5}{*}{$\begin{array}{l}\text { Online shopping takes less time to } \\
\text { purchase }\end{array}$} & Strongly Agree & 20 & 20.4 \\
\hline & Agree & 29 & 29.6 \\
\hline & Neutral & 30 & 30.6 \\
\hline & Disagree & 12 & 12.2 \\
\hline & Strongly Disagree & 7 & 7.1 \\
\hline \multirow{5}{*}{$\begin{array}{l}\text { Online shopping does not waste } \\
\text { time }\end{array}$} & Strongly Agree & 16 & 16.3 \\
\hline & Agree & 35 & 35.7 \\
\hline & Neutral & 24 & 24.5 \\
\hline & Disagree & 16 & 16.3 \\
\hline & Strongly Disagree & 7 & 7.1 \\
\hline \multirow{5}{*}{$\begin{array}{l}\text { Takes less time in selecting and } \\
\text { evaluating a product }\end{array}$} & Strongly Agree & 14 & 14.3 \\
\hline & Agree & 29 & 29.6 \\
\hline & Neutral & 28 & 28.6 \\
\hline & Disagree & 19 & 19.4 \\
\hline & Strongly Disagree & 8 & 8.2 \\
\hline \multirow{4}{*}{$\begin{array}{l}\text { I feel safe and secure while } \\
\text { shopping online }\end{array}$} & Strongly Agree & 12 & 12.2 \\
\hline & Agree & 25 & 25.5 \\
\hline & Neutral & 32 & 32.7 \\
\hline & Disagree & 17 & 17.3 \\
\hline
\end{tabular}




\begin{tabular}{|c|c|c|c|}
\hline \multicolumn{2}{|l|}{ Parameters } & \multirow{2}{*}{$\begin{array}{l}\text { Frequency } \\
12 \\
\end{array}$} & \multirow{2}{*}{$\begin{array}{l}\text { Percentage } \\
12.2 \\
\end{array}$} \\
\hline & Strongly Disagree & & \\
\hline \multirow{5}{*}{$\begin{array}{l}\text { Online shopping protects my } \\
\text { security }\end{array}$} & Strongly Agree & 9 & 9.2 \\
\hline & Agree & 26 & 26.5 \\
\hline & Neutral & 37 & 37.8 \\
\hline & Disagree & 16 & 16.3 \\
\hline & Strongly Disagree & 10 & 10.2 \\
\hline \multirow{5}{*}{$\begin{array}{l}\text { I like to shop online from a } \\
\text { trustworthy website }\end{array}$} & Strongly Agree & 29 & 29.6 \\
\hline & Agree & 27 & 27.6 \\
\hline & Neutral & 22 & 22.4 \\
\hline & Disagree & 10 & 10.2 \\
\hline & Strongly Disagree & 10 & 10.2 \\
\hline \multicolumn{2}{|c|}{ Total } & 150 & 100.0 \\
\hline
\end{tabular}

Above presented Table 2, has the detailed presentation of all frequencies and percentage of the data collected.

Here for gender the female category is a bit more than the male respondents. The age group 25 Years -30 Years has shown the highest as $41.8 \%$, so online shoppers in the Kurdistan region are mostly in the age between 25-30. Education level is important criteria for the usage of online shopping and this is very acceptable as customers with a bachelor degree were $57.1 \%$, this proves that it definitely is well educated people that tend to use online shopping. Most of the respondents are from the income group of USD 1500 - USD 2500. While shopping online, the delivery time is a major fact that satisfies customers and affects their behavior towards shopping, a high respondent is in agree and strongly agree category shows that they should definitely be receiving their purchases in much shorter period of time. Whether detail information is available about the products while shopping online, so according to customer's answers responses a high number lies in agree and strongly agree category. The next item is about whether customer is able to access and shop online at any time and it shows a strongly agree and agree again for the statement. The item asked for comparison online shows customers are unable to compare products in online shopping. The website design is a positive aspect that makes a difference in helping and makes the purchase easier. Safety is not a concern in online shopping stated by respondents. website layout is not very useful as per the understanding of respondents. The familiarity with a website reduces risks before purchasing any product is highly important accepted in the study. Most of the customer are in favor and they prefer to buy from a website that provides quality information. As per respondent's opinion the online shopping does not consume less time and the process is not faster. According to the results on online shopping and wastage of time respondents feel that yes it does waste time. The item regarding online shopping takes less time in selecting and evaluating a product, the response is, it takes more time. The item on whether customers feel safe and secure while shopping online and the response shows that they do not feel safe or secure while shopping online. Customers feel that online shopping protects their security or not, the case is not very clear as mostly have not been aware about usage of online shopping frauds. Asking on shopping from a trustworthy website, respondents are always seeking to have purchases from a very trustworthy website.

As discussed previously, 15 items are tested for One Sample T- Test on test value 4, where all items are showing highly significant result, items are presented with the outcome of SPSS further in the Table 3 below. 
Table 3: One Sample T-Test

\begin{tabular}{|c|c|c|c|}
\hline \multicolumn{4}{|c|}{ One Sample T-Test } \\
\hline \multirow[b]{2}{*}{ Items } & \multicolumn{3}{|c|}{ Test Value $=4$} \\
\hline & $t$ & df & Sig. (2-tailed) \\
\hline I get on time delivery by shopping online & -10.871 & 97 & .000 \\
\hline Detail information is available while shopping online & -11.398 & 97 & .000 \\
\hline I can buy the products anytime a day while shopping online & -10.508 & 97 & .000 \\
\hline It is easy to compare products while shopping online & -9.526 & 97 & .000 \\
\hline The website design helps me in searching the products easily & -12.112 & 97 & .000 \\
\hline I prefer to purchase from a website that provides safety & -11.683 & 97 & .000 \\
\hline Website layout helps in searching and selecting products & -12.346 & 97 & .000 \\
\hline Familiarity with website before purchasing reduces risks & -11.454 & 97 & .000 \\
\hline I prefer to buy from website that provides quality information & -9.995 & 97 & .000 \\
\hline Online shopping takes less time to purchase & -12.297 & 97 & .000 \\
\hline Online shopping does not waste time & -11.824 & 97 & .000 \\
\hline Takes less time in selecting and evaluating a product & -10.428 & 97 & .000 \\
\hline I feel safe and secure while shopping online & -8.998 & 97 & .000 \\
\hline Online shopping protects my security & -9.735 & 97 & .000 \\
\hline I like to shop online from a trustworthy website & -11.954 & 97 & .000 \\
\hline
\end{tabular}

Table 4: Correlations

\begin{tabular}{|c|c|c|c|}
\hline & & Customer Behavior & Online Shopping \\
\hline \multirow[t]{3}{*}{ Customer Behavior } & Pearson Correlation & 1 & $.875^{* *}$ \\
\hline & Sig. (2-tailed) & & .000 \\
\hline & $\mathrm{N}$ & 98 & 98 \\
\hline \multirow[t]{3}{*}{ Online Shopping } & Pearson Correlation & $.875^{* *}$ & 1 \\
\hline & Sig. (2-tailed) & .000 & \\
\hline & $\mathrm{N}$ & 98 & 98 \\
\hline
\end{tabular}

According to the correlation presented above in Table 4 , which has 0.875 as relationship in between Customer Behavior and Online Shopping. So the relationship is very strong and it justifies that Customer Behavior and Online Shopping in highly and positively correlated in Kurdistan region.

\section{Conclusion and Recommendation}

In short, e-commerce is a mixture of technology and business together, and this is as of the result of technological innovation appearing. E-commerce is the process of buying and selling products through websites and the internet. In the Kurdistan region people have recently started to establish online shopping websites such as, dasy2.com, Boombeena.com, erbilshoppingonline.com, kurdistanshop.info, kurdshopping.com, and kurdishfashion.com. However, for any type of new business to succeed, it depends on consumers buying behavior. Consumer buying behavior is known as an individual who purchases his/her needs in order to consume it, and this will satisfy the individual, because it helped the person to reach or get the thing that he/she needed. Studying consumer behavior is important, because it enables the market to know what type of products consumers want, and where and how the consumer will buy the product. Many studies have been done before in order to find out consumer behavior toward online shopping, and many factors have been discovered that affect consumer behavior such as, the external environment and the way of the consumers living, demography, customer satisfaction, services/products quality, quality of the website, decision making to buy online, personal characteristics, price, convenience, and security and trust. These factors are known to be the results of the studies which have been done previously in other countries. The aim of this study was to find out consumer behavior toward online shopping in the Kurdistan region, and as a result the number of the participants are female say there is not a big difference between them who answered the survey and the majority of the participants age was between ages of 25 to 30 , and they were university student, university teachers, and also employees of other private companies and UN. Gender has an important role which effects on consumer behavior, because females are shopping online more than male. Education also has an important role which affects the level of buying products and services online because whoever had high degrees of education had better income and it made people to buy online more than those people who do not have high income rates. This study showed that the major concern for Kurdish people to buy online is not having an online banking system where each person has an account and not enough instructions to learn how to use online shopping websites. Also factors that attracts consumer to shop online were shown as the variety of brands available to purchase online in this region, trust issues, and saving time, also shipment and delivery period of times was 
important, and quality of the products. A lot of these days show that they would like to shop online because according to the responds most participants who are not shopping would like to start shopping online because people think that, they can save time, and money, but the only barrier is limited access to online bank account and limited variety of products.

During research respondents recommended some important points in order to improve online shopping in Kurdistan region, and those points were as mentioned before better quality, adress system because in Kurdistan house numbers and street number are not available, and during receiving the product, it might go to wrong address or a place which is not available or may take a lot of time until they find the right address. These improvements will lead to reduce risks and will encourage people to buy more products online without thinking about the risks or difficulty of it. Another recommendation for improving online shopping in Kurdistan region is to encourage people to open online bank accounts, and government should support banks to protect people's accounts from fraud, and any kind of hacking, because people who are not shopping currently would like to start shopping online in near future, and if this issue is solved then more people will start online shopping, because it saves time and money.

\section{References}

Aggarwal, M. S. \& Hooda, S. (2012). Consumer Behavior toward E-Marketing: A Study of Jaipur Consumers. Journal of Arts, Science \& Commerce, Vol 3, 2(2).

Bashir, A.(2013). Consumer Behavior towards online shopping of electronics in Pakistan (Master's Thesis).

Chang, M. K., Cheung, W., \& Lai, V. S. (2005). Literature derived reference models for the adoption of online shopping. Information \& Management, 42(4), 543-559.

Folkestad, B. (2008). Analyzing interview data: Possibilities and challenges. Accessed at 1st of June, 2013.

Girard, T., korgoankar, P. \& Silverblatt, R. (2003). Relationship of Type of Product, Shopping Orientations, and Demographics with Preference for Shopping on the Internet. 18(1), 101-120. accessed at 12th Jan.2014.

Hasslinger A., Hodzic S. \& Opazo C. (2007). Consumer Behavior in Online Shopping.

Hughes, C. (2006). Qualitative and Quantitative Approach: Department of Sociology. Retrieved at 8th May 2013.

Jaafar, N. I. \& Jun, G. (2011). A Study on Consumers' Attitude towards Online Shopping in China.International Journal of Business and Social Science, Vol. (2) No. 22.

Jackson, S. (2008). Research Method: a Moduler approach. USA: Thomson Wadsworth.

Kajornboon, A. B. (2007). Using interviews as research instruments. Retrieved at $10^{\text {th }}$ May, 2013.

Kotler, Ph. (2004). Principles of Marketing. 3rd edn: Mc graw hill. Educational.

Li, N. \& Zh,P. (2002). Consumer Online Shopping Attitudes and Behavior: An Assessment of Research. Eighth Americas Conference on Information Systems.

Mahmood, M. A., Bagchi, K. \& Ford, T. C. (2004). On-line Shopping Behavior: Cross-Country Empirical Research. 9(1), 9-30. accessed at 12th Jan. 2014.

Marafie, A. H. (2008). Online Buying Behavior: the impact of demographics, shopping orientation, and risk perception on Kuwaiti customers.

Mirescu, S. V. (n.d.). The premises and the Evolution of Electronic Commerce. Journal of Knowledge Management, Economics and Information Technology, ISSN 2969-5934.

Muhammad Umar Sultan and MD Nasir Uddin, Itemnaire, consumers' behavior towards online shopping

Nayyar R. \& Gupta S. (2010). Impact of Changing Demographic Profiles of Indian Customers on their Internet Shopping Behaviour.

Reynolds, P. (1971). Aprimer in theory construction. Indianapolis. Bobbs-merrill

Salehi, M. (2012). Consumer Buying Behavior towards Online Shopping Stores in Malaysia. International Journal of Academic Research in Business and Social Sciences.

Sanati, F. (N.D.). E-Commerce Strategy for Southern Kurdistan Region.

Sward, M. D. (2008). Factors influencing the choice to shop online: a psychological study in a South African context.

Teo, T. S. (2002). Attitudes toward online shopping and the Internet. Behaviour \& Information Technology, 21(4), 259-271.

Zheng, F. (2006). Internet Shopping and its Impact on Consumer Behavior (Master's Thesis). 